\title{
EDUCATION FOR SELF-GOVERNMENT: REASSESSING THE ROLE OF THE PUBLIC SCHOOL IN A DEMOCRACY
}

\author{
Charles R. Lawrence III*
}

Compelling Belief: The Culture of American Schooling. By Stephen Arons. New York: McGraw-Hill Book Co. 1983. Pp. $\mathrm{xi}, 221 . \$ 19.95$.

Every government degenerates when trusted to the rulers of the people alone. The people themselves therefore are its only safe depositories. . . An amendment of our constitution must here come in aid of the public education. The influence over government must be shared among all the people. If every individual which composes their mass participates of the ultimate authority, the government will be safe; because the corrupting the whole mass will exceed any private resources of wealth .... 1

Thomas Jefferson's vision of public education as a custodian of democracy survives at the core of what most Americans believe about public schools. Most of us were educated in public schools. We believe that public schools provide the best opportunity for most Americans to learn the skills and responsibilities of citizenship. An attack on public schools is often viewed as an attack on democracy.

Stephen Arons' book, Compelling Belief, is a forceful and provocative challenge to the ideology of public schooling. While Jefferson saw the public schools functioning as a guardian against the tyranny of political elites, Arons describes a system that suppresses dissent, cannibalizes culture and threatens the vitality of the democratic process.

Arons' thesis is a radical one. He argues that the present political and financial structure of American schooling is unconstitutional. His argument is straightforward: (1) The rights of freedom of speech and freedom of the press protected by the first amendment include "the right to read, and freedom of inquiry, freedom of thought [and] freedom to teach. . ." (p. 200). ${ }^{2}$ (2) Schooling inevitably involves the

* Visiting Professor of Law, Stanford University. Professor of Law, University of San Francisco. B.A. 1965, Haverford College; J.D. 1969, Yale University. Professor Lawrence is the coauthor (with Joel Dreyfuss) of THE BAKKE CASE: THE POLITICS OF INEQUALITY (1979). - Ed.

1. T. Jefferson, Notes on Virginia, in 4 Works of ThOMAs JefFerson 64-65 (Federal ed. 1904) (Jefferson's explanation of his "Bill For The More General Diffusion of Knowledge").

2. Quoting Justice Douglas in Griswold v. Connecticut, 381 U.S. 479,482 (1965). This view is not a novel one and Arons notes that it has been advanced by such noted authors as 
transmission of values or the establishment of some beliefs or world views and the stigmatization of others. ${ }^{3}$ (3) Schooling is compulsory. The state operates the public schools and only those families with sufficient financial resources are free to choose non-public schooling. When these non-public alternatives threaten majoritarian values they are extensively regulated (pp. 85-185). (4) This constitutes government control of content in the education of a captive audience and thereby violates the first amendment. 4

A central purpose of the first amendment is the protection of the vitality of a political process that relies upon the informed consent of the governed for its legitimacy. But there can be no consent, Arons argues, where the governed are subject to involuntary governmental manipulation of consciousness:

The society that utilizes the institutional power of involuntary schooling to reduce an individual's control over the development of personal conscience and consciousness threatens to make that individual politically impotent. Under these conditions the government becomes a kind of political perpetual-motion machine, legitimizing its long-term policies through the world view and public opinion it creates. [P. 203].

Arons' thesis is grounded in constitutional theory, but Compelling Belief is happily a book that reaches beyond first amendment doctrine to explore the human feelings and social dynamics that are the flesh and bones of first amendment conflicts. In a series of case studies, constructed from interviews with parents, school officials and their lawyers, Arons examines a variety of disputes involving the censorship of curriculum in American schools and analyzes the legal and political implications of these disputes over what children shall be taught. This approach to the analysis of an abstract legal principle, by exploring the perceptions and feelings of those who are directly affected, maintains an engagement with reality often absent in

Thomas Emerson, p. 201, and Alexander Meiklejohn, p. 202. The Supreme Court has long recognized that the first amendment embraces the freedom to teach. See, e.g., Barenblatt v. United States, 360 U.S. 109, 112 (1959); Sweezy v. New Hampshire, 354 U.S. 234, 249-50 (1957). Recent case law has also acknowledged a first amendment right to acquire information. See Board of Educ. v. Pico, 457 U.S. 853 (1982); First National Bank of Boston v. Bellotti, 435 U.S. 765 (1978); Virginia State Bd. of Pharmacy v. Virginia Citizens Consumer Council, 425 U.S. 748 (1976).

3. The Supreme Court has acknowledged that the public schools are "vitally important . . . vehicles for inculcating fundamental values necessary to the maintenance of a democratic political system." " Board of Educ. v. Pico, 457 U.S. at 864 (quoting Ambach v. Norwick, 441 U.S. 68, 76-77 (1979)).

4. For a contrasting view see, J. TuSSMAN, Government AND THE Mind 51-85 (1977) arguing that the state has an important "teaching power" that involves inducting children into the community and that makes such notions as children's free speech or state ideological neutrality irrelevant. See also Diamond, The First Amendment and Public Schools: The Case Against Judicial Intervention, 59 TEx. L. REV. 477 (1981); Goldstein, The Asserted Constitutional Right of Public School Teachers to Determine What They Teach, 124 U. PA. L. REV. 1293 (1976). 
conventional constitutional scholarship, where the appellate opinion is used as the point of departure.

Arons' case analysis is divided into three parts which introduce variations on two central themes. The themes are not hopeful. The first is a saga of "corrosive, irreconcilable, and proliferating conflict" (p. vii) among fearful parents who find their children growing up "amidst a rubble of collapsed cultural meanings and dysfunctional social values" (p. viii). Arons notes that "up to 30 percent of the nation's school districts have experienced book and curriculum conflicts in the past few years ..." (p. 14). He describes the public burning of books in Warsaw, Indiana, the banning of Solzhenitsyn in Maine, and of Malamud and Langston Hughes in Levittown, New York.

Maurice Sendak's four-year-old character Mickey must wear Magic Marker shorts in In the Night Kitchen lest the kindergartners of Springfield, Missouri, be corrupted. The texts of Oregon must not cast aspersions on the Founding Fathers, and those of Louisiana must teach the benefits of free-enterprise economics. Sex-role stereotypes must be removed from books in Montgomery County, Maryland; the juniorhigh-school children in one district of New York City may not read about life in Spanish Harlem; books are screened for racial sterotypes and Huck Finn is finished in Winnetka, Illinois. The legislature of Arkansas insists that Genesis be given equal time with evolution; whole dictionaries are banned because they contain multiple definitions for "bed," "knock," and "shack." [P. 15].

Arons argues that today's school censorship wars, like the wars over state religions fought in the seventeenth and eighteenth centuries, represent an attempt to "transform private values into public orthodoxy" (p. 193). The censorship epidemic is a symptom of societal malaise. Parents who experience deep value conflict or uncertainty seek "to impose meaning on social order and, in the process, to define personal identity" (p. 21). The public schools have historically been viewed as a remedial source of social cohesion, and have become a natural vehicle for these efforts at achieving personal salvation by invoking the power of the state to coerce the beliefs of others. ${ }^{5}$

The causal connection between parents' search for personal identity and the school censorship battles in which they engage makes religious warfare a particularly appropriate analogue. It is the inten-

5. Arons notes that this vision of the public school as a vehicle for social cohesion through coerced socialization or value inculcation is an essential element of a public school ideology that envisions that it is "possible, desirable, and even essential to prescribe a system of values that is best for everyone." P. 123. For a historical review of the ideology supporting compulsory schooling, see Everhart, From Universalism to Usurpation: An Essay on the Antecedents to Compulsory School Attendance Legislation, 47 REv. EDUC. RESEARCH 499 (1977). See also M.

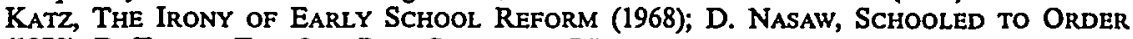
(1979); D. TYACK, THE ONE BEST SYSTEM (1974). 
sity of emotion that accompanies conflict over religious or ideological values that leads Arons to conclude that such disputes are "irreconcilable"6 and can only result in the debilitating polarization and factionalism that the framers of the Constitution sought to avoid by forbidding state-sponsored religion.

Arons' solution is to pursue the analogy to its logical conclusion. The first amendment establishment clause's prohibition against the state inculcation of relgious beliefs ${ }^{7}$ should be extended to secular ideologies as well. Because education cannot be value neutral the government must be excluded from the business of education. ${ }^{8}$

Arons' approach is especially attractive when one considers the confusion and incoherence of the Supreme Court's most recent decision concerning school censorship, Board of Education v. Pico. ${ }^{9}$ The Justices' several opinions make apparent the difficulty of providing a coherent standard for resolving school censorship disputes without directly confronting and resolving the contradiction between the government control of compulsory schooling and intellectual freedom. ${ }^{10}$

The justices are unanimous in their acceptance of the indoctrinative function of the public schools. But the existence of constitutional limits upon the power of the state to control speech in schoolrooms or usurp the family's role in the socialization of children is equally clear. ${ }^{11}$ Justice Brennan, writing for a plurality of the Court, finds himself on the horns of a dilemma, the resolution of which requires the creation of several distinctions of dubious sub-

6. Arons does not believe that all conflict over world views and beliefs is necessarily irreconcilable. On at least two occasions he refers to the possibility of the constructive use of conflict, pp. $x, 132$, but in each instance he gives little attention to the possibility. He indicates that while techniques such as mediation are likely to be more successful than court proceedings in resolving these disputes, he is not sanguine about its capabilities where attitudes and world views concerning who should control a child's education are involved.

7. See, e.g., Abington School Dist. v. Schempp, 374 U.S. 203 (1963); Engel v. Vitale, 370 U.S. 421 (1962).

8. Arons argues for the ultimate extension of Pierce v. Society of Sisters, 268 U.S. 510 (1925), which, in invalidating an Oregon statute requiring all children to attend public schools, noted that "[t]he child is not the mere creature of the State," 268 U.S. at 535, and ruled that the Constitution's fundamental theory of liberty "excludes any general power of the State to standardize its children by forcing them to accept instruction from public teachers only." 268 U.S. at 535. See Arons, Separation of School and State: Pierce Reconsidered, 46 HARv. Educ. REv. 76 (1976).

9. 457 U.S 853 (1982).

10. By a 5 to 4 vote the Court refused to dismiss the students' first amendment claims and remanded them for trial. But of the five justices voting to remand, only three, Brennan, Marshall and Stevens, could fully join in an opinion; Blackmun joined in part of the plurality opinion but wrote a separate concurrence and White concurred in the judgment, stating that a trial was needed to develop the factual record. Justices Burger, Powell, Rehnquist and O'Connor dissented.

11. 457 U.S. 853 at $864-65$ (citing West Virginia Bd. of Educ. v. Barnette, 319 U.S. 624 (1943), Epperson v. Arkansas, 393 U.S. 97 (1968), and Tinker v. Des Moines School Dist., 393 U.S. 503 (1969)). 
stance. Brennan says that the Court is not intruding "upon [the] school board's discretion to prescribe curricula" because the library books at issue in this case are "optional rather than required reading." 12 He then argues that it is significant that this case involves the removal of books from the library and not a decision about what books should be acquired.13 Finally, Justice Brennan stresses the distinction between a curricular decision that is politically or morally motivated and a decision that is "based solely upon the "educational suitability' of the books in question."14

It is far from clear why library reading is protected by the first amendment when it is voluntary but would not be if made a required part of the curriculum. Likewise the removal/acquisition distinction seems a difference too easily subject to formalistic manipulation to survive serious substantive scrutiny. Would the Island Trees School Board have acted constitutionally if it had required that each student read a selection of books from the library or if it had sold the entire library collection and then reacquired all but the ten books in question?

Initially, the distinction between "political" and "educational" motives seems more authentic. Censorship that is justified by characterizing the censored material as "anti-American, anti-Christian, anti-Sem[i]tic and just plain filthy" 15 obviously violates the first amendment's prescription against the regulation of political speech based on its content. And civil libertarians are less offended when the same decision is couched in the more neutral sounding professional educators' jargon of "suitability," "relevance" and "appropriateness to age and grade level."16 But if the transmission of values is an appropriate educational task, the "educational suitability" of a book may be determined at least in part by its political content. The school board's determination that a book is inappropriate for a grade

12. 457 U.S. at 862.

13. 457 U.S. at 862 .

14. Thus whether petitioners' removal of books from their school libraries denied respondents their First Amendment rights depends upon the motivation behind petitioners' actions. If petitioners intended by their removal decision to deny respondents access to ideas with which petitioners disagreed, and if this intent was the decisive factor in petitioners' decision, then petitioners have exercised their discretion in violation of the Constitution. . . . On the other hand, respondents implicitly concede that an unconstitutional motivation would not be demonstrated if it were shown that petitioners had decided to remove the books at issue because those books were pervasively vulgar. . . [or] if it were demonstrated that the removal decision was based solely upon the "educational suitability" of the books in question...

457 U.S. at 871 (footnote omitted).

15. When the Island Trees Union School Board removed the books from the library shelves it issued a press release so characterizing the removed books. 457 U.S. at 857.

16. The Board appointed a book review committee and instructed the committee to make its recommendations based on "educational suitability," "good taste," "relevance," and "appropriateness to age and grade level." The committee's recommendations were substantially rejected by the Board without any statement of reasons for doing so. 457 U.S. at 857-58. 
level may be based on moral judgments about if or when children should be exposed to certain kinds of material.

Arons identifies two additional problems with the plurality's attempt to limit the Pico decision to those cases in which the censor's intent is to impose a recognizable political or moral point of view upon the school. The first is the difficulty of providing a legally satisfactory standard for determining when a prohibited public school orthodoxy exists.

[J]udges have indicated that they want to know exactly what is being forced down students' throats before the law will acknowledge the right of free inquiry . . . but these beliefs are rarely systematically organized or easy to identify or articulate ... . Antifeminism, for example, can be seen running through the efforts of many censors, yet proving that these people are seeking to impose a monolithic view of human relationships is extremely difficult . . . [Pp. 70-71].

A second problem in applying this approach is that the political censorship in most public schools is a negative one: "When the prevailing orthodoxy consists of learning to be superficial and unresponsive and to live a bureaucraticized life without rebelling, it is no wonder that judges ask for, and civil-liberties lawyers cannot really provide, a capsule definition of the dominant ethic of schools or censors" (p. 71).

There is much that is appealing in an anti-establishment doctrine that applies to political as well as religious indoctrination. It is a clearer and more easily applied standard and is consistent with first amendment doctrine regarding the regulation of speech. But if the remedy for the unconstitutionality of government schools is the privatization of education, it becomes less clear that we have discovered a counterweight to the deadening forces of prevailing orthodoxy.

Even if we imagine the best of circumstances, where the schools are run by well-informed and caring groups of parents rather than IBM or Sears, those who control the school will impose their own brand of truth and justice on the children in their charge. But the absence of government involvement in this censorship and the theoretical availability of alternative forums for learning will bar any first amendment claims. Legitimate conflict will only exist where those seeking the power of indoctrination within a private institution are relatively evenly matched, and once one side has been held the victor others will not have cause to complain.

There may be much virtue in maintaining an arena where ideological conflict is perceived to be legitimate. Later in the book Arons recognizes the importance of school disputes as a forum for more broad-based social criticism. Having catalogued the most often heard complaints about public schools, he reminds us that "the perceived orthodoxy these families oppose is characteristic not simply of 
schools but of the culture in general" (p. 101). Moreover, despite the efforts of public school bureaucrats to exclude parents from their professional turf, parents continue to organize to regain control of the schools. The fact that their children's consciousness is at stake legitimizes their struggle as does their feeling that they understand what their children need as well as anyone. When the schools are public, and at least theoretically subject to their governance, their involvement is further legitimized. ${ }^{17}$ Perhaps we should hesitate before abolishing one of the only remaining fora where public debate is viewed as legitimate and accessible to common people. ${ }^{18}$

Arons never explicitly advocates the substitution of privately controlled schools for the present public system, ${ }^{19}$ but such a result is necessarily implied in his first amendment analysis. It is an implication that bears further exploration because there is substantial danger that an apparent antidote for the disease of coerced orthodoxy may, in fact, advance the malignancy. If Arons is correct that value neutrality in education is impossible, the incoherence of the Pico decision should convince us that he is also right that government control of compulsory education and the first amendment's prohibition against established ideology are irreconcilable. But a solution that requires the substitution of schools controlled by the private sector relies upon a formalistic constitutional distinction between public and private that may simply disguise the wolf of government coercion in sheep's clothing. By framing his social/political analysis within first amendment doctrine Arons incurs the danger of unintentionally incorporating all of the ideological baggage of that doctrine and in so doing advancing the very cancer it is his purpose to cure.

Several critical commentators have described the process by which law has been made a vehicle for the transmission of ideological imagery that helps to preserve and legitimize existing power relationships. ${ }^{20}$ The legal system is used by those in power to achieve

17. See generally P. Gabel, The Mass Psychology of the New Federalism: How the Burger Court's Political Imagery Legitimizes the Privatization of Everyday Life (March 1982) (paper presented at conference on critical legal studies) (arguing that the role of law in maintaining the power of elites is to be found not in the direct practical consequences of its decisions with the politics of these outcomes being mystified by ideology - but rather in the ideology itself as a set of cultural images that are intended to give a false political legitimacy to the existing social order).

18. Arons recognizes the function that public schools serve as a forum for debate of larger societal issues. "School conflict is a microcosm of social stress because schooling is accessible politics. Conflict over schooling is visible, local, and more nearly legible than any other aspect of public policy debate." P. 90.

19. Arons does include a critical assessment of a District of Columbia "tax credit" plan that was defeated by the voters in 1981, pp. 215-21, but he makes clear that it is not the book's purpose to make or comment upon specific proposals for increased choice in education. P. 214.

20. See, e.g., D. Hay, P. Linebaugh, J. Rule, E.P. Thompson \& C. Winslow, Albion's Fatal TREE (1975); Freeman, Legitimizing Racial Discrimination Through Antidiscrimination Law: A Critical Review of Supreme Court Doctrine, 62 MINN. L. REv. 1049 (1978); Gabel \& Feinman, Contract Law as Ideology, in The Polmics of Law: A Progressive CritiQue 172 
results in individual legal disputes that maintain the status quo. What is less obvious, but perhaps more important, is the use of legal ideas as a means of creating and transmitting utopian images that serve to justify that status quo. By representing reality in ideal terms the law validates the socio-economic context in which legal decisions are made. The ideological imagery masks or denies the reality of oppressive or alienating social or economic relations and persuades us that they are fair. ${ }^{21}$

Recent developments in first amendment law involve just such a distorting ideological representation. In Buckley v. Valeo 22 and First National Bank of Boston v. Bellotti ${ }^{23}$ the Supreme Court invalidated attempts to mitigate the effects of concentrated wealth on state and federal elections. The Court held that a congressional statute limiting campaign expenditures and a Massachusetts statute barring the use of corporate funds to influence the outcomes of referenda violated the first amendment. ${ }^{24}$ This extension of the first amendment's protection to corporations and wealthy politicians contains the ideal image of a shared interest in free speech between the wealthy and society as a whole. The ideal image of equal access to the marketplace of ideas, or those social and political fora where our ideas may gain acceptance is substituted for the reality of a mass media and electoral process that is dominated by the wealthy.

Private schools are free to engage in religious and ideological indoctrination because the Constitution only prohibits governmental abridgement of speech. ${ }^{25}$ In the absence of state action the courts

(D. Kairys ed. 1982) (reviewed in this issue); Gordon, New Developments in Legal Theory, in id., at 281; Kennedy, The Structure of Blackstone's Commentaries, 28 BUFFALo L. REv. 205 (1979); Lawrence, "Justice" or "Just Us": Racism and the Role of Ideology (Book Review), 35 STAN. L. REV. 831 (1983).

21. Professors Peter Gabel and Jay Feinman have noted, for example, that in the nineteenth century the law of contracts generated a new ideological imagery that helped persuade workers to accept the social dislocation, alienation, and class domination embodied in the Industrial Revolution:

The legitimatizing image of classical contract law . . . was the ideal of free competition as the consequence of wholly voluntary interactions among many private persons, all of whom were in their nature free and equal to one another. ... It did not take account of the practical limitations on market freedom and equality arising from class position or unequal distribution of wealth. . . The legitimation of the free market was achieved by seizing upon a narrow economic notion of freedom and equality, and fusing it in the public mind with the genuine meaning.

See Gabel \& Feinman, supra note 20, at 176.

22. 424 U.S. 1 (1976).

23. 435 U.S. 765 (1978).

24. In Bellotti the Court held that the principle of nondiscrimination among speakers dictates that "speech that otherwise would be within the protection of the First Amendment [does not lose] that protection simply because its source is a corporation . . . ." 435 U.S. at 784. In Buckley the rule that speech may not be deliberately suppressed was transformed into the more abstract proposition that the quantity of speech may not be deliberately reduced. Therefore, campaign expenditures may not be limited by Congress.

25. U.S. Const. amend. XIV, § 1. See also The Civil Rights Cases, 109 U.S. 3 (1883). The 
will not hear the free speech claim of a child or her family who complains of school censorship. ${ }^{26}$ Furthermore, the school itself has first amendment rights. ${ }^{27}$ It is this affirmative right to institutional free speech $^{28}$ that contains the seeds of ideological illusion. ${ }^{29}$ If we accept the imagery that posits a community where all private individuals and institutions have roughly equal access to the resources required to make themselves heard, we are likely to be persuaded that intellectual freedom requires first amendment protection for private school indoctrination whether those schools are run by the local church or Xerox Corporation.

Because Compelling Belief focuses on the problems created by value inculcation in government run and regulated schools we may lose sight of the fact that powerful private institutions play at least as significant a role in the manipulation of public consciousness. The average American child spends about 1000 hours in school each year, but the same child also spends in excess of 1300 hours per year in front of the television. ${ }^{30}$ With the advent of cable television it becomes increasingly apparent that the mass media and the corporate sponsors who pay its bills are a far greater danger to pluralistic thought than the public schools. ${ }^{31}$

In Parts Two and Three Arons examines the experience of two groups of individuals who have sought to escape the orthodoxy of the public schools. The home education movement and the rapid

limitations of the state action doctrine appear to make a great deal of sense in this circumstance. In addition to the generally applicable concern for diluting judicial lejgitimacy through indiscriminate constitutional intervention, see, e.g., A. BiCKEL, THE LEAST DANorrous BRANCH 128 (1962); J. ELY, DEMOCRACY AND DisTRUST (1980); L. LUSKY, BY WHAT RIOHT? 50-53 (1975), one might well argue in this instance that the opportunity for school choice or alternative forums for learning and expression precludes a right to free speech in a particular private school.

26. Cf. Hudgens v. NLRB, 424 U.S. 507 (1976).

27. "Academic freedom, though not a specifically enumerated consitutional right, long has been viewed as a special concern of the First Amendment." Regents of the Univ. of Cal. v. Bakke, 438 U.S. 265, 312 (1978); see also Sweezy v. New Hampshire, 354 U.S. 234, 263 (1957).

28. See notes 22-23 supra and accompanying text.

29. It should be noted that the state action limitation contains similar ideological imagery. For a discussion of this phenomenon see Lawrence, supra note 20, at 847-48. See also Olsen, The Family and the Market: A Study of Ideology and Legal Reform, 96 HARV. L. REV. 1497 (1983); Brest, State Action and Liberal Theory: $A$ Case Note on Flagg Brothers v. Brooks, 130 U. PA. L. REv. 1296 (1982).

30. "[S]tudies show the average American child (age 9 to 12) will spend about 1,000 hours in classrooms over the course of a year, but 1,340 hours in front of a television set. And by the time that child completes high school, he will have spent 22,000 hours of accumulated viewing time before the television screen and only 11,000 hours of classroom time." Today's Children Listen More To TV Than Teachers, Christian Science Monitor, Oct. 17, 1983, at 6, col. 1.

31. It will be argued that television's role in consciousness manipulation is distinguishable from that of the schools in that one is not compelled to watch television. But this argument begs the question. Just as Arons has noted that only those with the requisite financial resources have true choice in schooling, television is for many the only real accessible and affordable source of public information and entertainment. 
growth of fundamentalist schools are contrasting responses of families who "sense that the assumptions of the majority culture have lost their power of explanation . . " (p. 192). Arons finds that both of these groups of dissenters face governmental resistance and regulation that is far out of proportion to the threat which they might pose to either the public school system or the children involved. We learn that when parents choose to educate their children at home they may be convicted of criminal violations, charged with neglect, separated from their children, forced to move out of state, or jailed. When Christian Academies in Kentucky refused to comply with a complex and detailed set of state regulations the state board ordered local school officials to enforce the truancy laws against parents of children attending those schools and threatened to bring actions against the principals and teachers for "unlawful transaction with a minor" (p. 158). "Why is it that millions of children who are pushouts or dropouts amount to business as usual in the public schools," Arons asks, "while one family educating a child at home becomes a major threat to universal public education ...." (p. 88)? "In none of these cases did anyone seriously question the health or happiness of the children or suggest they were being abused or neglected in any way other than in their parents' failure to send them to schools most people attend" (p. 89). Arons identifies the unifying element in these cases as government hostility to dissent (p. 191). He describes a government bureaucracy that is not so much fearful of a particular segment of the political spectrum (religious fundamentalists and counterculture hippies alike are repressed), as they are of the fact that these families have actively rejected the public school ideology that the majority culture represents the best answer for all. Again Arons' concern is not simply with the personal price which individual dissenting families must pay but with the damage done to the political process.

The problem for the society at large is that by repressing dissenting values, seeds of future consensus and social cohesion are destroyed. Especially in matters of child rearing and school socialization, the repression of dissenting values is a method of cannibalizing culture. [P. 196].

Arons concludes his discussion with a brief evaluation of one of the more widely discussed proposals for increasing family choice in education, the tuition tax credit plan. ${ }^{32}$ In concluding that a recently defeated Washington, D.C. initiative "must be regarded as unsatisfactory and counterproductive" (p. 216), Arons identifies three

32. Arons analyzes the "Greater Educational Opportunities Through Tax Incentives" initiative. P. 216. Washington, D.C. voters defeated this initiative by a two-to-one majority on November 3, 1981. Arons' discussion remains timely. A similar plan is being circulated in California as a proposed state constitutional amendment, and President Reagan has supported a federal tax credit plan. 
broad questions that must be addressed in evaluating any proposed restructuring of American education:

1. Would the new structure remove economic discrimination in the choice of schools and prevent some families from pricing others completely out of the market, thereby becoming truly voluntary for families complying with compulsory education requirements?

2. Would the new structure provide a clear and enforceable policy that race discrimination in any form and in any aspect of schooling is illegal?

3. Would the new structure protect individuals, families, and schools from government manipulation of beliefs and world views? Is the direct or indirect regulation of family choice or school content prohibited except where compelling justifications exist? [P. 220].

Arons clearly recognizes the enormous pragmatic difficulties of fashioning a plan that merits an affirmative answer to the first two questions and remains politically viable. ${ }^{33}$ His third question raises theoretical problems as well. If individuals, families, and private schools are to be protected from government manipulation of beliefs except where compelling justifications exist, we must determine what constitutes a "compelling justification." Are there values or beliefs that are of sufficient import to or impact upon society to justify coerced consensus?

Arons directly confronts the conflict between individual liberty and racial equality. The achievement of racial equality in all aspects of schooling is, for him, the clearest case of a "compelling interest of overwhelming importance" (p. 218). ${ }^{34}$ But if it is clear that a claim to first amendment protection of religious or political belief will not prevail against government enforcement of racial equality in access to education, what is the correct result when racism is part of the explicit or implicit curriculum or is officially condoned among a student's peers? Should the result be different when schools exclude women, or teach female children that they are less worthy or able than their brothers or that they should aspire only to traditional women's roles? ${ }^{35}$

33. See Arons \& Lawrence, The Manipulation of Consciousness: A First Amendment Critique of Schooling, 15 HARV. C.R.-C.L. L. REV. 309, 341-59 (1980).

34. Despite his concern for government value coercion that is achieved through overregulation of private schools, pp. 137-85, Arons favors clear and enforceable regulation of racial discrimination in schools; including, for example, the determination of whether testing, tracking, disciplinary policies or admissions policies are racially discriminatory. See p. 218 (discussing the D.C. tax credit plan). See also Bob Jones Univ. v. United States, 103 S. Ct. 2017 (1983), where the Court held that private religious schools with racially discriminatory policies could be denied tax exemption by the I.R.S. because the governmental interest in eliminating racial discrimination in education was compelling and substantially outweighed whatever burden denial of tax benefits placed on the petitioner's exercise of their religious beliefs. For a provocative discussion supporting the result reached in Bob Jones University and offering a constitutional rationale therefor see, Bell, What Color Was Jesus? Religious Freedom and Racial Justice in Modern America, - TEX. L.REv. - (1983).

35. Title IX of the Education Amendments of 1972, 20 U.S.C. $\S \S 1681-1686$ (1976), which 
But these questions merely restate the ever present dilemma of how one makes liberty and equality compatible. Arons has taken a first and important step in leading us to a more explicit examination of the liberties to be weighed in the balance.

There is, however, another important question that must be asked. That is, what is the role of the state in protecting the interests of the child vis $a$ vis the child's parents? ${ }^{36}$ By focusing his analysis on the relationship between the government and the family, Arons avoids addressing the intra-familial conflicts which may exist when parental values and children's interests diverge. Arons does acknowledge that "there are families in which the children dissent from parents' decision(s)" and "children who do not accept the substance of what their parents seek to indoctrinate in them" (p. 98). But having noted the importance and intractability of the problem of conflict within families he suggests that its resolution must await another day. ${ }^{37}$ It is understandable that the author should choose to defer discussion of a set of issues that would merit an additional

prohibits discrimination on the basis of sex by covered educational institutions contains specific exemptions for religious institutions and undergraduate colleges which have always been single sex institutions. See 20 U.S.C. $\$ \S 1681$ (a)(3), (5) (1976). The Statute does not include coverage for discriminatory curriculum materials. See also Vorcheimer v. School Dist. of Philadelphia, 430 U.S. 703 (1977) (upholding the constitutionality of a sex-segregated secondary school). But see Mississippi Univ. for Women v. Hogan, 458 U.S. 718 (1982); cf. Olsen, supra note 29 . Frances Olsen has argued that the ideology which posits the family as a private sphere which should remain immune from state intervention ignores the fact that the state has traditionally ratified the social roles assigned to family members (for example, that parents are decisionmakers and disciplinarians or that women should be subservient to their husbands). "The notion of noninterference in the family depends upon some shared conception of proper family roles, and 'neutrality' can be understood only with reference to such roles." 96 HARv. L. REV. at 1506. Thus when we invoke familial liberty to preserve the right of the family patriarch to send his daughter to a school that teaches her that she should not aspire to be a nuclear physicist, we may actually be preserving a status quo born of an earlier state intervention.

36. This question is distinct from the question of whether the state has interests in promoting collective values unrelated to the well-being of the individual child. In Wisconsin v. Yoder, 406 U.S. 205 (1972), for example, the court concluded that the interests served by Wisconsin's compulsory education law (those of preparing citizens for effective, intelligent and self-reliant political and social partipation), were ably served by the training and support provided in the community life of the Old Order Amish who withdrew their children from school after the first eight grades. While the court indicated that it would not permit the state to impose its idea of the "best possible life" as a justification for intrusion on religious freedoms, it never directly considered the interests of the children themselves in developing independent lifestyles or pursuing options at odds with the views and aspirations of their families. As Justice Douglas observed in dissent, allowing the Amish parents a religious exemption operated "to impose the parents' notions of religious duty upon their children." 406 U.S. at 242 (dissenting in part).

37. To explore the complexities of the relationship between child and parent in home schooling; to plumb the psychology of rebellion, coercion, growth, and autonomy within these families; to relate these family patterns to a pragmatic theory of children's rights and the role of family in society would require another research project altogether. It will have to suffice here to observe that the rights of children in families will probably be easier to understand and protect once the consequences of overbearing state pressures on the families themselves have been articulated.

Pp. 98-99. 
book, but in this case the postponement of consideration results in the omission of an important step in Arons' first amendment analysis.

The state historically played a minimal role in protecting children, but that role has gradually increased. ${ }^{38}$ Today we view the government as having significant responsibility for the protection of minors, even from their parents. ${ }^{39}$ Any attempt to strike the appropriate balance between familial liberty and the governmental interest in the coerced imposition of collective values on families must consider the state's interest in protecting the children within those families.

The conflict between parental liberty and the state's role in safeguarding the well-being of minors is most directly presented in the literature that has examined laws providing for state intervention on behalf of abused and neglected children. ${ }^{40}$ Here there is also a preference for family autonomy as against state intervention, but the determination of the best interest of the child remains a critical, if not the primary, inquiry. ${ }^{41}$ Children clearly have important interests, the parental abrogation of which would not amount to abuse or neglect. For example, a child has an interest in being exposed to the kind of information, experiences and adult support that will enable him or her to grow into a mature, responsible and independent adult. The child's interest in eventual adult autonomy may require an ability to exercise options which his or her parents would consider morally foreclosed. The failure of parents to provide their children with an education that maximizes their future independence would hardly warrant the severe state intrusion involved in removing a child from parental custody. But the same interest might justify the more limited coercive intervention of government-regulated compulsory schooling.

38. For a good historical overview see Areen, Intervention Between Parent and Child: $A$ Reappraisal of the State's Role in Child Neglect and Abuse Cases, 63 GEo. L.J. 887, 894-917 (1975).

39. See Prince v. Massachusetts, 321 U.S. 158 (1943). See also S. Katz, WHEN Parents FAIL (1971); R. KEMPE \& C.H. KEMPE, ChILd AbUSE (1978); Areen, supra note 38.

40. See J. Goldstein, A. Freud \& A. Solnit, Before the Best Interests of the ChILd (1979); J. GoldsteIn, A. Freud \& A. Solnit, Beyond THE Best INTERests of THE CHILD (1973); Crouch, An Essay on the Critical and Judicial Reception of Beyond the Best Interests of the Child, 13 FAM. L.Q. 49 (1979); Mnookin, Foster Care: In Whose Best Interests?, 43 HARV. EDUC. REV. 599 (1973), reprinted in THE RIGHTS OF CHILDREN 158 (Harv. Educ. Rev. ed. 1974); Wald, State Intervention on Behalf of "Neglected" Children: Standards for Removal of Children from Their Homes, Monitoring the Status of Children in Foster Care, and Termination of Parental Rights, 28 STAN. L. Rev. 625 (1976); Wald, Thinking About Public Policy Toward Abuse and Neglect of Children: A Review of Before the Best Interests of the Child (Book Review), 78 Mich. L. REv. 645 (1980); Symposium, The Relationship Between Promise and Performance in State Intervention in Family Life, 9 ColuM. J.L. \& Soc. ProBs. 28 (1972).

41. See notes $39-40$ supra. 
One might ask, for example, whether the state has an interest in insuring that adolescent children receive sufficient instruction in sex education to make intelligent choices about their sexual behavior. One could ask further whether this interest overrides the liberty of parents who do not believe their children should receive such information. Will the state's interest in requiring a curriculum that does not confine young women to learning stereotyped roles and skills be viewed as compelling if its goal is protecting the emotional health and future options of girls whose parents' values would restrict their development as full human beings?

The answers to these questions are far from obvious. What is clear is that they must be asked and that Arons' constitutional analysis remains incomplete by their omission.

Compelling Belief is at its best in conveying the intensity and complexity of emotion that surrounds our individual and collective struggle to give our lives meaning through the lives of our children. One wishes for more of Arons' sensitive reportage and compelling narrative. If the book has a weakness it lies in the author's attempt to find an answer to the complexity he observes in the formalism of conventional constitutional doctrine. But perhaps this is only to fault the craftsman for the bluntness of the tools that the law has provided him.

Compelling Belief challenges us to evaluate our assumptions about the role of schooling in the preservation of the democratic process. The high priests of public education are certain to complain that this book attacks one of the last bastions of democracy. But those who share Jefferson's concern that the mass of people should continue to control their own destinies ${ }^{42}$ would do well to accept Arons' challenge to examine critically how our schools can best serve the dual purpose of instilling shared community values and promoting the diversity of thought that vitalizes the process by which we determine what values we share.

42. See note 1 supra and accompanying text. 